\title{
Roundtable discussion: Thinking together from within the times that worry us
}

\author{
Olga Cielemęcka \\ University of Turku
}

\section{Monika Rogowska-Stangret}

University of Warsaw

Polish-Japanese Academy of Information Technology

\section{Gurminder K. Bhambra}

University of Sussex

\section{Andrea Pető}

Central European University

\section{Jessie Loyer}

Mount Royal University

\section{Mariya Ivancheva}

University of Liverpool

\section{Nanna Hlín Halldórsdóttir}

University of Iceland,

\section{Received: 4/11/2019}

Accepted: 02/12/2019

DOI: https://doi.org/10.1344/jnmr.v1i1.29204

\section{Abstract}

The inaugural section of "Praxiography: practices and institutions" of Matter: Journal of New Materialist Research features a roundtable discussion between five scholars who address matters pertaining to practices, legacies, and affects that comprise today's academia. Preceded by editors' introduction, Gurminder K. Bhambra, Andrea Pető, Jessie Loyer, Mariya Ivancheva, and Nanna Hlín Halldórsdóttir offer their reflections on ways of organising, living, and imagining various research and academic praxes by means of thinking with the concepts of resistance, collaboration, 
solidarity, care, and kinship and consider them from feminist, de-colonial, Indigenous, and other anti-oppressive perspectives.

\section{Keywords}

Academic practices, higher education, decolonization, precarity, feminist practices of care

\section{Introduction}

We are worried. About job security and student debt. About political climate and climate change. In Hungary the right-wing government of Viktor Orbán withdrew accreditation and funding from gender studies programmes; in Turkey, academic freedom is under threat and signatories of the "Peace Petition" (organized by a group Academics for Peace and circulated in January 2016) face prison time; and the antiLGBTQ and anti-feminist sentiments are on the rise. For us, as curators of this roundtable, being worried about the state of things provided an impulse to offer a space and a time to worry together as a collective practice of hearing each other out: acknowledging others' concerns, sharing our own and thinking how we as academics could respond to what preoccupies us. We are researchers working within academia - sometimes against it, at its fringes, and sometimes beyond it. This is why in this panel discussion we wanted to situate and start a conversation about things that trouble, upset, and fill us with worry with regards to "our own backyard," the world of academia. Academia is a heterogeneous terrain - in terms of power relations, communities it affects, includes, and excludes, voices it mis/represents, narratives it legitimises, wipes out, or creates. Academia is a microcosm of a sort, in which precarious working conditions, neoliberal exploitation, and hopes for the better future percolate through each other. We wish to zoom into some of those worries and dreams, lessons and strategies, "values and facts [...] cooked together as part of one brew" (Barad et al., 2012, p. 16) in today's university. 
As editors of a section "Praxiography*: practices and institutions" 1 of a new academic journal Matter: Journal of New Materialist Research we wanted this roundtable discussion to provide an opportunity to engage with topics of research practices, critique of institutional structures, and to host bold explorations of ways of organising, living, and imagining various research/academic praxes. Thus, we aim at politics of new materialisms that is about putting feminist new materialisms to work (Dolphijn \& van der Tuin, 2012, p. 101) through diffracting theoretical reflection, personal experiences and practice in search for more just and liveable ways to think, feel, and act. To this effect we invited five scholars, whose activism and theoretical inventiveness have been an inspiration to us, to share their insights on the state of today's university from their own situated (Haraway, 1988) perspectives. The voices gathered here contribute to the politics of feminist new materialisms by directing our readers' attention to questions of knowledge production, canons, and classifications and, specifically, by thinking how to destabilize them. These objectives - to our minds - are central to feminist new materialisms.

Our intention was to bring together their distinct voices and feminist, Indigenous, decolonial, and anti-oppressive perspectives on practicing as researchers, teachers, and activists - rooted both in academic environments and in our respective communities. The invited contributors are not necessarily coming from feminist new materialisms' perspectives or identify themselves with this body of work. We strongly believe that offering spaces for dialogue across disciplines, theoretical standpoints, methodologies, generations, and various feminist genealogies to which we are indebted constitutes an effort to break outside of the often limiting borders and classifixations (van der Tuin, 2015) and to share worries, struggles, experiences, coping strategies, and solidarity beyond them.

1 The term "praxiography" was coined by Annemarie Mol (2002) and, independently, developed by members of working group "New Materialisms: Tackling Economical and Identity Political Crises and Organizational Experiments" of COST Action IS1307 New Materialism: Networking European Scholarship on "How Matter Comes to Matter". See Allhutter et al. (2019). 
Thinking about our own worries and shared concerns from within our academic situatedness and wondering about the ways in which academia may respond to contemporary political, environmental, and social crises and systemic violences, we encouraged our invited authors to approach the following five notions:

Resistance: We asked: In times of "anti-gender mobilization", the rise of anti-migrant sentiments and the far-right, which forms of organizing and resisting make you hopeful? What are we up against and what tools to respond do we have as members of the academic community?

Collaboration: How can we imagine academic practices and collaborations otherwise, be it through, for example, (more collectively oriented) research, teaching, organizing (e.g. academic events, work, institutional structure, etc.), peer-reviewing, writing, or publishing?

Solidarity: It seems that today we're seeing many examples of intersectional and transnational practices of solidarity. We're thinking for example about the support for Polish struggles against the abortion ban coming from all over the world, especially places like Argentina or South Korea. From your perspective, what is your take on how solidarity and support travel between various contexts or struggles? This also makes us wonder what needs to be done for gestures of "solidarity" and support not to reproduce the same-old white and western routes of power?

Care: Within neoliberal institutions of higher education academics face challenges concerning the quality of their lives, precarious forms of employment, and responsibility as teachers and researchers for both their work and its relevance and for their students, mentorees, colleagues, and collaborators. We see care as an important term that could help us negotiate between resilience, self-care, and the care for one's (academic) community. How might care be practiced in academia?

And finally, kinship, as a notion that makes us think about how practicing care, solidarity, and collaboration is rooted in our own "situatedness", meaning the concrete context or place from which we speak. This situatedness includes, among other 
things, our feminist histories or traditions, genealogies, and intergenerational influences. How does such "locality" inform your own practice?

Those questions were meant as an inspiration and a gesture of welcoming to enter a conversation. We felt grateful and touched by the depth of the received responses, and the generosity of the contributors as they shared their insights, strategies, and experiences with us and the readers of this journal.

This assemblage of feminist voices is opened by Gurminder K. Bhambra, scholar of postcolonial and decolonial studies. In her reflexive piece she identifies colonial legacies and the stakes of decolonizing the university: which communities the universities serve, which kinds of narratives create which kinds of worlds, and how to "do the work"? Gender studies scholar, Andrea Petö, shares reflections on how to "do the work" of feminist resistance in the context of "anti-gender mobilization" in Hungary and the lessons learnt from it. She encourages the reader to think how resistance may emerge from within shared precariousness and vulnerability. Jessie Loyer, an Indigenous (Cree-Métis) librarian, talks about responsibility for and accountability to her genealogies and communities and how it grounds her work. How to mobilize notion of academia that responds to the needs of a collective, how to produce knowledge that "actually creates collective" (Puig de la Bellacasa, 2012, p. 203), how - being an academic - to be attentive to the fact that - paraphrasing Haraway - everything comes with its world. Anthropologist and sociologist Mariya Ivancheva directs our attention to how new technologies (initially promising) work in neoliberal university contributing to community-unbuilding practices and performing new forms of exclusion, exploitation, and precarity. How are we to respond? Feminist philosopher Nanna Hlín Halldórsdóttir shares a personal account of her struggles within, against, and beyond neoliberal academia. She meanders between the economic crash and health problems, speeding up and slowing down, learning and unlearning, individual tiredness and collective efforts. "Why am I still here?" asks Halldórsdóttir and we learn how much energy and tiredness the response requires.

There is a political dimension to being worried, preoccupied, tired, disappointed. Much as there is to anger (Lorde, 1984), complaint (Ahmed, 2018), or depression 
(Cvetkovich, 2012). The recognition of possible modes of resistance, care, or solidarity needs time to think, to worry, to create connections, and to take responsibility for how we produce knowledge and imagine academia. We wish to invite readers to read the following five short essays. They are distinct in many ways: writing styles, academic backgrounds, their author's situatedness, and theoretical approaches. They diagnose different reasons to be worried about and offer various ways to stay with what worries and act. We do not wish to close this variety with concluding remarks from the curators as we believe we are just in the middle of grasping what political stakes may emerge from sharing worries. We think of this roundtable as an open and ongoing invitation to rethink resistance, collaboration, solidarity, care, and kinship with our authors and readers.

\section{Bibliography}

Ahmed, Sara (2018, May 30). Time of complaint. Feministkilljoys [blog]. Retrieved from https://feministkilljoys.com/2018/05/30/the-time-of-complaint/.

Allhutter, Doris; Bargetz, Brigitte; Brøgger, Katja; Cielemęcka, Olga; Meissner, Hanna; González Ramos, A. María; Revelles Benavente, Beatriz; RogowskaStangret, Monika: Staunæs, Dorthe; Stark, Whitney \& Thiele, Kathrin (2019). The politics of new materialism and organizational experiments in academia. [Article submitted for publication]

Barad, Karen; Juelskjær, Malou \& Schwennesen, Nete (2012). Intra-active entanglements - an interview with Karen Barad, Kvinder, Køn \& Forskning, 1-2, 10-23.

Cvetkovich, Ann (2012). Depression: A public feeling. Durham, London: Duke University Press.

Dolphijn, Rick \& van der Tuin, Iris (2012). New Materialism: Interviews \& cartographies. Ann Arbor: Open Humanities Press. 
Haraway, Donna (1988). Situated knowledges: The science question in feminism and the privilege of partial perspective. Feminist Studies, 14(3), 575-599.

Lorde, Audre (1984). Sister outsider: Essays and speeches. Berkeley: Crossing Press.

Mol, Annemarie (2002). The body multiple: Ontology in medical practice. Durham, NC: Duke University Press.

Puig de la Bellacasa, María (2012). "Nothing comes without its world": Thinking with care. The Sociological Review, 60(2), 197-216.

Van der Tuin, Iris (2015). Generational feminism: New materialist introduction to a generative approach. Lanham: Lexington Books.

\section{Decolonising the university: some reflections}

Gurminder K. Bhambra, University of Sussex

In recent years, there has been a coalescence of various movements and campaigns under the broad term, "decolonising the university" (see Bhambra et al., 2018). These have included movements such as Rhodes Must Fall and Fees Must Fall in South Africa, as well as Rhodes Must Fall Oxford in the United Kingdom, and broader movements for curriculum reform across a variety of countries. This, in turn, has provoked - too numerous to cite - media commentators, politicians, and academics from the UK, Hungary, Australia, Brazil, among other places, to warn against the threats posed to the very foundations of Western civilisation and its institutions if such calls are heeded. It is quite illuminating how quickly and how intense the pushback against any call for change within the university has been. The university, as John Dewey argues, is one of the vital repositories of the common learning of communities (see Holmwood, 2011). If we accept this understanding of the university then we should also recognise that, as those communities change, so our understandings of the present and the past are also transformed. What people seem to be concerned with, then, is the changing composition of the communities that universities serve. Let me use gender here as a way to illustrate the issues and point to how such 
concerns are longstanding. While I will focus on the UK, I suggest that the arguments I make are pertinent across a variety of sites.

When universities in the UK opened up to women in greater numbers in the postwar period, and especially after reforms which created a system of mass higher education in the 1960s, one of the first things that women found was that women could not be found in these institutions. For some female scholars, this absence required address. In terms of the curriculum - of knowledge production - this was done by seeking to identify women as both the objects and subjects of research and by coming to argue for the need of a feminist perspective across disciplines and other areas of study (see Bhambra, 2007). They addressed both what was to be taught as well as who should teach and, in the process, changed these institutions. Within the UK, it is not a mainstream opinion to suggest that the curriculum or universities are being distorted or disfigured by the inclusion of women and feminist perspectives. So, what are we to make of those who criticise the call to decolonise our institutions?

Just as some men found gender equality a challenge to their sense of self, it's not surprising perhaps that those whose sense of self is intimately tied to the idea of Empire having been a force for good in the world, are unsettled by arguments to the contrary. In this context, what I find surprising is how they locate such criticisms as forms of identity politics when it is quite clear that the only politics of identity being peddled here is their own.

Any number of commentators, on being confronted by the trade in human beings, often respond by saying, yes that was bad, but we did abolish the trade. It is correct that Britain did abolish the trade, after over 200 years of profiting from it, but this is not the only thing that was done. As Catherine Hall and Nicholas Draper have made publicly known, Britain also paid compensation of $£ 20$ million - or $£ 65$ billion in today's money, or the equivalent of $40 \%$ of GDP - to those people who had lost property in the process (see Hall et al., 2014). Just to be clear, enslaved people were not compensated for their loss of liberty; rather the people who had owned other people as property were compensated for their loss. This money was used to fuel the 
industrial revolution, build country houses, and endow public schools, Oxford and Cambridge colleges, and art institutions.

In February 2018, the Treasury rather ineptly tweeted that "we", that is British taxpayers, did not finish paying off the bond that had been raised to pay out this compensation until 2015. Yes, current taxpayers, and their parents and grandparents and great-grand-parents - not just in the British national state, but across its imperial provinces - paid through taxes to compensate British slave-owners and their descendants for ending the abomination that was slavery. This fact either rarely makes it into standard discussions of abolition or, if it does, there's usually some muttering about the rule of law and the necessity to compensate for the loss of property however distasteful we might find the fact that people - in a different time, with different moralities, etc. - regarded it legitimate to own other people.

This claim, however, is not then followed by agreement with the idea of more general reparations to compensate those across the colonial empire who had lost property. That is, those who were dispossessed from their lands, whose right to property in themselves was taken from them, or in compensation for the resources that were extracted - to the tune of $\$ 45$ trillion from India alone as the economist Utsa Patnaik (2017) has calculated. If the rule of law and the right to be compensated for property lost is central to who we think we are - is central to all articulations of British values - then why not generalise the process and compensate all those others? What is the obstacle to doing so? Saying that "we know that slavery was wrong because we abolished it" erases the historical narratives of those who had always opposed slavery - including successfully as in the Haitian Revolution (see Bhambra, 2016). It also pretends that we knew it was wrong prior to others telling us so, even as we argue that it is not possible to judge the past according to the standards of the present. Which is it? Because logically you cannot have it both ways.

The reason for presenting this extended example is to say that decolonising the curriculum, fundamentally, is about transforming the "common-sense" narratives we have about how the world we share in common was configured. What I have argued about British colonialism is true of the colonialisms of other European countries. It 
also includes those who believe themselves to be exempt because their own states were not significant contributors to colonialism and imperialism. Yet, all settler colonies were constituted by the "emigrationist colonialism" of populations across Europe -including Northern and Eastern Europe. For example, during the nineteenth century, over two million Polish people moved to the lands that come to be known as the Americas, as did over a million Swedes, constituting about a fifth of the total Swedish population. This was a movement of populations that benefitted those that remained as well as those that moved. If we do not adequately understand the shared histories that produced us, we have no hope in constructing a politics that will effectively address the many challenges we face.

Our institutions of learning are complicit in such reproduction to the extent that they do not adequately challenge the politics of selective memory that is reproduced every time we evade our past instead of confronting it directly and honestly. Yet, standard philosophies of science argue that knowledge proceeds through changing previous "selections", opening up to new "objects" of inquiry, and reconstructing concepts and categories to provide new understandings of what we thought we knew. "Decolonising" is properly thought of as integral to what constitutes the very meaning of a curriculum.

To end, I want to offer three suggestions of what could be done to transform our curricula and our institutions of learning. Firstly, do the work, whatever you understand the work to be in the context of the broader projects of social justice that are the necessary ground for any work within the university. Do not let, in Tuck and Wang's (2012) widely cited refrain, decolonisation be a metaphor and do not think that decolonisation is going to happen primarily in the university (although it is also needed in the university). Secondly, following Toni Morrison (1975), don't get distracted; whether by social media or by those demanding you prove the legitimacy of your own existence. Just do the work. Thirdly, remember that the injunction to selfcare was not an end in itself, but that if you did not look after yourself you couldn't serve your community. The processes in need of being dismantled and transformed 
have been in train for over 500 years and so the work that continues to be needed is extensive and requires us to work together.

There is little that matters in this context other than doing the work. And, in doing the work, we are doing the work of the university as properly understood - as constituting the university as a repository of the common learning of communities.

\section{Acknowledgements}

I would like to thank the reviewers and editors for helpful comments on this paper. All errors are, as ever, my own.

\section{Bibliography}

Bhambra, Gurminder, K. (2007). Sociology and postcolonialism: Another "missing" revolution? Sociology, 41 (5): 871-84.

Bhambra, Gurminder, K. (2016). Undoing the epistemic disavowal of the Haitian revolution: A contribution to global social thought. Journal of Intercultural Studies, $37(1): 1-16$.

Bhambra, Gurminder, K.; Nişancioğlu, Kerem \& Gebrial, Dalia (Eds.) (2018). Decolonizing the university. Pluto Press: London.

Hall, Catherine; Draper, Nicholas; McClelland, Keith; Donington, Katie \& Lang, Rachel (2014). Legacies of British slave-ownership: Colonial slavery and the formation of Victorian Britain. Cambridge: Cambridge University Press.

Holmwood, John (2011). The idea of the public university. In J. Holmwood (Ed.), $A$ manifesto for the public university. London: Bloomsbury Academic.

Morrison, Toni (1975). A humanist view. Speech at Portland State University, Oregon. Retrieved from https://soundcloud.com/portland-state-library/portlandstate-black-studies-1. 
Patnaik, Utsa (2017). Revisiting the "drain", or transfer from India to Britain in the context of global diffusion of capitalism. In S. Chakrabarti and U. Patnaik (Eds.), Agrarian and other histories: Essays for Binay Bhushan Chaudhuri. Tulika Books: New Delhi.

Tuck, Eve \& Yang, K. Wayne (2012). Decolonization is not a metaphor. Decolonization: Indigeneity, Education \& Society, 1(1): 1-40.

\section{After resistance: Lessons learned from banning gender studies in Hungary}

Andrea Pető, Central European University

In October 2018, the Hungarian government's decree revoked license of a two-year study program in gender studies without giving any explanation and without having consulted with professional institutions nor the accreditation committee (Petö, 2018a). There were two universities in Hungary where this accredited Master's program was taught: at Central European University (CEU), a private university in English that receives no public funding since 2006, and at Eötvös Loránd University (ELTE), a public university in Hungarian with public funding from 2017 (Pető, 2018b). The Hungarian government crossed the line when intervening in the field of education with an ideological agenda and its action evoked bad memories of communist censorship.

Gender recently became the centre of political debates. To explain how that happened, based on our analyses of situations in Poland and Hungary, together with Eszter Kovats and Weronika Grzebalska we came up with the concept of "gender as symbolic glue". Symbolic glue is a metaphor that is somehow able to tap into people's feelings of uncertainty about the world around them and direct them against equality issues. It also generates dynamic discussions. Gender works as a symbolic glue in different ways. First, the notion of gender is constructed in such a way that it becomes perceived as a threatening concept. The right has united separate contested issues and attributed them to the umbrella term of "the progressive agenda". And then there 
is the concept of "gender ideology", which is constructed by those who consider gender as a concept to demonstrate the failure of liberal democracy. The opposition to this so-called "gender ideology" has become a means of rejecting certain facets of the current social and economic order, from the prioritisation of identity politics over material issues such as labour conditions or housing to the weakening of people's social, cultural and political security. Secondly, the demonization of "gender ideology" has become a key rhetorical tool in the construction of a new concept of common sense for a wide audience, a form of consensus of what is normal and legitimate. It is important to note that this social mobilisation against "gender ideology" and political correctness does not just demonise the worldview of liberal democracy and reject the human rights' paradigm which has long been the object of relative consensus in Europe and North America. But the anti-equality movements also offer a livable, viable alternative centered on the family, the nation and religious values, as well as freedom of speech. This alternative to the neoliberal progressive narrative is widely attractive because it offers a positive identification of individual's own choices, and it promises a safe and secure community as a remedy for individualism and social atomisation. Thirdly, the opposition to "gender ideology" is also a possibility for the right to create a broad alliance and unite various actors that have not necessarily been eager to cooperate in the past. That is why fighting against those forces who use the concept of gender and equality to mobilize hate and exclusion is an imperative not only for gender studies scholars independently. It is also an imperative to admit that we have lost a battle in this war. "Gender as symbolic glue" has an impact on those who have been attacked and it creates very clear fronts gluing together those who are victims of these vicious attacks, they stick together in collective resistance.

I am, nevertheless, optimistic because I believe that the lessons learned during the past years living, working and teaching in illiberal Hungary will help the fight for academic freedom. Previously scholars of gender studies were marginalised, even spatially: working in their offices in the attic or in the cellar of the university building. Now due to the anti-gender studies campaign, Hungary, a country of ten million inhabitants, became a country of ten million gender experts! Everybody seems to 
have an opinion about the course curricula and reading lists, learning outcomes or the labor market opportunities of gender studies' graduates.

The first lesson learned in this struggle was the importance of networks, international contacts and press relations. Responding to media inquiries, prioritizing media outlets, explaining the complex situation for often unprepared and overworked journalists required time and special media skills we had to acquire. The second lesson was the understanding of the surprising weakness of European feminist infrastructure. It was not major organizations, such as AtGender (European Association for Gender Research, Education, and Documentation) that collected signatures in support of gender studies programs in Hungary. It was a dedicated and politically savvy scholar, David Paternotte, who collected more than a hundred signatures from Masters' programs in gender studies across European Union. The European professional organisation of gender studies scholars and professionals, AtGender works well in "normal" times as it became just another fee paying professional organisation, which is organising academic conferences. But gender studies have never been and will not be just another profession especially not now. Therefore, AtGender failed to serve as a major lobbying and interest protecting tool during major crises partly because it defined its role in academic setting when academia is losing its lobbying power more and more. The quick and effective support came from established professional networks and institutionalized organizations; from feminist sociologists, historians, political scientists who quickly wrote protest letters (and organized letters sent by their universities) and signed petitions despite their own workload. And that is another lesson learned; that writing letters and signing manifestos is not enough. European professional organizations like European University Association and All European Academies issued statements calling for protection of academic freedom and gender studies but they all received the same standardized general answer from the Hungarian government. The protest and support letters are evidence that there are scholars and institutions that are resisting and despising the politics of the Hungarian government and its attack on gender studies but in practice their protest had little impact. The EU Commissioner whose portfolio is to protect academic freedom and European values 
ignored the event referring to education as national competency. (It is not an accident that this Commissioner, Tibor Navrasics who was appointed by FIDESZ party previously played an active role building up the present 'System of National Cooperation' (NER) of Hungary). Education is a national competency in Europe therefore the national governments can regulate it as they wish. When the nation state is captured by a small group then it can do whatever its members want regarding regulating education.

During the debate around gender studies it became obvious that feminist academics trained to describe and define social and political contexts, may be missing some essential political skills: how to think and achieve what can be and not only write peer reviewed articles about theories of resistance. The lack of political imagination beyond the feeling of upset and protest needs to be critically examined in the future. Constant reflection, deconstruction and analysis of what has happened and why cannot substitute effective strategizing about the future.

The ban galvanized students and young people to take action. Gender studies scholarship is not dead in Hungary. An increasing number of applications for the CEU Gender Studies Program, now moved to Vienna, Austria, demonstrates that gender studies are considered a "cool" discipline. We have lost the accredited program in Hungary but our gender studies community is facing this failure with dignity and united. The same courses are being offered in Hungarian at ELTE but they do not count towards a degree in gender studies. CEU continues to offer MA program in gender studies accredited by the State of New York. For the academic year of 20192020 more applications were submitted to CEU Gender Studies than ever before, unfortunately the students start their study program in Vienna as the Hungarian government does not accept the US accreditation.

The recent strike on 18th November 2018 at the universities of ELTE, Corvinus and CEU proved that gender is more relevant than ever. During this protest, professors of these three universities in Budapest discussed issues that previously were mostly ignored, such as incorporation of gendered perspectives in the curricula of various university courses, referencing female authors and promoting their work. What is this 
if not gender mainstreaming in the best sense of the word? These issues would not have been brought up had the government not banned a discipline of gender studies. The ban was a wake-up call for all of us to save not only the discipline but to fight for free academic research as such.

\section{Bibliography}

Kovats, Eszter; Grzebalska, Weronika \& Pető, Andrea (2017, January 13). Gender as symbolic glue: how "gender" became an umbrella term for the rejection of the (neo)liberal order. Political Critique. Retrieved from http://politicalcritique.org/long$\mathrm{read} / 2017 /$ gender-as-symbolic-glue-how-gender-became-an-umbrella-term-for-therejection-of-the-neoliberal-order/.

Pető, Andrea (2018a, November 29). Hungary's attack on Gender Studies. Public Seminar. Retrieved from http://www.publicseminar.org/2018/11/hungarys-attackongenderstudies/?fbclid=IwAR1J2NknFuBxY_6N6YQPK7ASRKOsJVbd7T1JpKM QIzZsV7THRMZVOQ2M84k.

Pető, Andrea (2018b). Eastern Europe: Gender research, knowledge production and institutions. In B. Kortendiek, B. Riegraf, K. Sabisch (Eds.),_Handbuch Interdisziplinäre Geschlechterforschung (pp. 1-11). Wiesbaden: Springer VR.

Engenderings. Blog by LSE Gender Studies features several case studies as well as theoretical insights https://blogs.Ise.ac.uk/gender/.

\section{Genealogies of an Indigenous librarian: How nêhiyaw (cree) kinship laws might structure reciprocity in teaching research}

Jessie Loyer, Mount Royal University, Canada

When Indigenous researchers state their tribal affiliation, they are performing a rhetorical act of accountability. When I say that I am a Cree and Métis researcher and librarian, it's not a fun fact about my genetic makeup; it's not percentage-based 
identity or blood quantum politics. Researchers in Indigenous Studies, when they state their affiliation, are letting their audience know who they are responsible for and accountable to. This statement marks the communities that make this research possible.

The ways we explicitly call our communities into our writing and our presentations lays out a foundation of accountability and responsibility and helps to position researchers in a genealogy. It confronts the myth of a single scholar toiling alone. None of us emerge from nothing: we are all the result of generations of relationships.

There are so few Indigenous librarians that we are often the only one in our library system. But I begin my career as a student librarian at the only Indigenous academic library in Canada, working at the Xwi7xwa library at the University of British Columbia. My colleagues, Kim Lawson (Heiltsuk) and Sarah Dupont (Métis), were my mentors. Being one of three Indigenous librarians granted a freedom from singularity, to not need to be all things to all people. When I began incorporating more theory in my practice, I encountered the work of Loriene Roy, an Anishinabe librarian, who writes about an ecology of Indigenous librarianship that focuses on community rather than self, with "less emphasis on tools than on the relationships between people and their connections to traditional knowledge" (Roy, 2015). Roy's interest in relationships is echoed in the work of Deborah Lee, a Cree-Métis-Haudenosaunee librarian, who found that the university, and by extension, the library, fails to be reciprocally responsible: Indigenous students felt that libraries had "a lack of services recognizing the Indigenous values of 'being in relationship' and reciprocity” (Lee, 2001). We are called to maintain good relations and reciprocal relationships as a means of survival and well-being for both librarians and students.

Both Lee and Roy embrace relationality as a key focus for librarianship from an Indigenous perspective. For us, information literacy instruction - the way that librarians teach students about how to find, assess, navigate, and use information is primarily concerned about relationships. And, if we are in relationship, we need to be reflective about being reciprocal members in that relationship. 
Reciprocity within a nêhiyaw and Michif legal system asks us to be responsible in very particular ways to the people we teach. We know our relatives through wâhkôhtowin; miyo-wîcêhtowin directs us to be in good relationship. Kinship connections here extend beyond the family, to the rest of creation, grounded in the land. This legal system extends from the land (see Campbell, 2007; Macdougall, 2010; Innes, 2013; Adam, 2015).

With wâhkôhtowin animating my teaching as a librarian, my work is informed by Caswell and Cifor's ideas about radical empathy shaping what a feminist ethics of care looks like in cultural memory institutions. Unsurprisingly, their vision is centred in relationships: "archivists are seen as caregivers, bound to records creators, subjects, users, and communities through a web of mutual affective responsibility" (Caswell and Cifor, 2016). We recognize that research is more than a mental exercise, and navigating academic structures by doing research is never a solitary act. Academic structures tend to privilege certain structures of relationality: citation, for example, is a kind of genealogy (Ahmed, 2013; Tuck, Yang, \& GaztambideFernández, 2015). Yet, in the same way that my literature review positions my paper's particular genealogy, when I say l'm Cree and Métis, from Michel First Nation, raised in Calahoo, I mark my kinship responsibilities and accountabilities.

If we consider positionality as a key feature of research, we start by querying how a writer came to their question. Indigenous researchers have long known that their research is animated by their communities and their connection to their territories, but researchers of all kinds might consider the ways that their research is reciprocal, or insurgent, responsive to the needs of communities rather than extractive (Gaudry, 2011). A framework of insurgent research might be a fundamental way to not only articulate genealogies, but to make this kinship practicable. Imagine how the research landscape could be radically shifted if we began all projects by asking what the community needed.

The work I do is grounded by my genealogies: from the work of Indigenous librarians who see the primacy of relationships in teaching information literacy, from the Cree legal traditions, particularly the laws of wâhkôhtowin and miyo-wîcêhtowin, and from 
an ethic of care that sees research as insurgent, not extractive. It is grounded, in all things, by the land that sustains me, as I attempt to nurture ongoing, reciprocal research relationships.

\section{Bibliography}

Ahmed, Sara (2013, September 11). Making feminist points. Feministkilljoys [blog]. Retrieved from https://feministkilljoys.com/2013/09/11/making-feminist-points/.

Campbell, Maria (2007, November 5). We need to return to the principles of wahkotowin. Eagle Feather News. Retrieved from https://www.eaglefeathernews.com/quadrant/media//pastlssues/November_2007.p df.

Gaudry, Adam, J. P. (2011). Insurgent research. Wicazo Sa Review, 26(1), 113136.

Innes, Robert Alexander (2013). Elder Brother and the Law of the People:

Contemporary kinship and Cowessess First Nation. Winnipeg, CA: University of Manitoba Press.

Lee, Deborah, A. (2001). Aboriginal students in Canada: A case study of their academic information needs and library use. Journal of Library Administration, 33(3-4), 259-292.

Macdougall, Brenda (2010). One of the Family: Metis culture in nineteenth-century northwestern Saskatchewan. Vancouver, B.C: UBC Press.

McAdam, Sylvia (2015). Nationhood interrupted: revitalizing Nêhiyaw legal systems. Saskatoon, SK, Canada: Purich Publishing Limited.

Roy, Loriene (2015). Advancing an Indigenous ecology within LIS education. Library Trends, 64(2), 384-414. 
Tuck, Eve; Yang K. Wayne \& Rubén Gaztambide-Fernández, R. (2015, April).

Citation practices. Critical Ethnic Studies. Retrieved from

http://www.criticalethnicstudiesjournal.org/citation-practices.

\section{Unbundling: A new gendered frontier of exclusion and exploitation in the neoliberal university}

Mariya Ivancheva, University of Liverpool

Unbundling is the process of disaggregating educational provision into its component parts likely for delivery by multiple stakeholders, often through public-private partnerships and the use of digital approaches (Swinnerton et al., 2018). A neutral definition, it relates to a process that is all but neutral to higher education. Having done research on unbundling South African and English universities, on a project focused on teaching and learning processes, I could not help but realise the extent to which this process affects much more than student learning and online teaching material curation patterns. Under the premise of widening access, it contributes to a potentially profoundly gendered casualisation, automation, deprofessionalisation, and fragmentation of academic labour to new unforeseen degrees. In this, unbundling reveals a new frontier of exploitation and exclusion at universities that we need to be aware of and organise against.

Initially unbundling followed a commons- rather than market-led imaginary (Mansell, 2017). Radical educators saw digital technologies' potential to democratise education and widen access. Shorter, low-cost, flexible unbundled curricular units could be made available online and used by atypical students still at a disadvantage in education: women, people with caring responsibilities and disabilities, mature fulltime working students. Employers could support job-tailored workers' education, and communities could become more involved with universities, demanding need-based content. Such a radical "digital disruption" of the original elite "bundle" of residential university degrees could challenge elite distinctions and transform university education through technologically innovative pedagogies. 
Yet, unbundling did not happen in vacuum. It happens in the era of neoliberal globalisation that sees rampant commercialisation of the higher education marked by quantified competition for excellence and success measured by metrics of individual performance and world rankings. This homogenising vision of the global field of higher education (Marginson, 2008) gives an upper hand to research over teaching, makes English-language publications the only valid academic currency, introduces new governance systems into academic work and services, and raises student fees, debt, and anxiety. It makes research dependent on external funding and researchonly precarious staff, and teaching - on a growing number of teaching-only staff bought out to replace fundraising core academics.

To understand to what extent workers and students carry out the burden of this system: in the UK alone (a public-mostly system of higher education with over 160 universities) there was a record $£ 44$ billion surplus in higher education (Bennett, 2018). Yet in the same year academic pensions fund USS was to be put on the market and individual contributions raised (Povey, 2018). And while universities try to compete for "teaching excellence" to allow them to uncap already exorbitant student fees (Hale \& Vina, 2016), students are taught by over $50 \%$ precarious faculty (UCU 2013; 2016) and student debt has risen to $£ 1$ billion (CBDU, 2018). In this scenario, it is rather cynical that online learning, rather than better investment in faculty recruitment and stability and student stipends, is considered a panacea by managers. The way this argument looks, taken to its logical consequences: content can be automated, put online, and facilitated by workers often trained to a postgraduate or post-PhD level with ever more precarious deprofessionalised contracts: content curators, forum managers, online support officers - their job descriptions proliferate and they are invisible, fragmented and isolated. Meanwhile universities use public-private partnerships with billion-revenue corporations to provide technology and online platforms where these courses "take place". Such corporations - around 60 world players on a market currently estimated at over 3 billion (out of a 30+ billion edtech market worldwide) and predicted to reach 7.7 billion by 2025 (HolonIQ, 2019) - are increasingly endowed with the financial and the symbolic capital of universities to run online short-courses and programs on their 
behalf. They reap the benefits from online learning on two levels - first by being paid hefty sums for content to be disposed on their platforms, and a second time - for the "learning analytics" big data they collect from the growing student population joining online courses worldwide and sell it to big businesses to hone their local and global marketing strategies.

This process is paralleled by a growing casualization of higher education - a process that affects not only contractual relations, but also means a broader "existential and structural uncertainty" of academics and workers in general (Butler, 2009). It allows university workers to be contracted with ever shorter, more flexible fixed-term conditions, in which basic justice (Frazer, 2016) redistribution (rights and benefits), recognition (visibility and career development options), and representation (in decision-making and union contestation) is increasingly curtailed. In academia this process happened since the 1970s through the erosion of tenure that leaves many at jeopardy of lack of security to plan ahead personally and professionally. In this, precarity becomes more than contractual insecurity and starts being the lack of (self-)care and access to practices of love, care, and solidarity, of control of one's own time and space, and enclosure of academic freedom from the market pressures exposing workers to such arrangements (Ivancheva et al., 2019). The careless lives of monastic scholars is now extended onto a very diverse post-PhD population doomed to the Hobson's choice of (hyper)mobility vs (hyper)flexibility (Ivancheva et al., 2019).

Academics are pushed to constantly look for employment outside their area of residency making a return to their original place of origin impossible (Stalford, 2008). With public systems of welfare, child- and elderly-care curtailed by privatisation and austerity in Eastern and Western Europe alike, and not even available in many contexts beyond Europe, moving becomes a taxing effort of losing immediate kinship networks providing such services out of necessity. Women are at a double disadvantage. Partnered women, who have to make decisions around childbirth and childcare within certain age limits (ESF, 2009; Ivancheva et al., 2019) are discriminated against by recruitment panels based on being mothers (González et 
al., 2019) or the improbability of male partners moving location to stay with female spouses (Rivera, 2017). The latter scenario makes single women with(out) children the only mobile female academics, but as they are often doing more emotional and admin work, they often are at disadvantage of ever forming a family (Ivancheva et al., 2019). Black and Minority Ethnic faculty and even less so Black faculty's (Joseph, 2019) probability of women being hired in permanent academic position at all is in times lower than female white or any male candidates (Advance HE, 2018).

Thus, women and members of ethnic minorities are pushed into the raising teachingonly contracts, made invisible for research positions, and career development (Courtois \& O'Keefe, 2015). In this, they are made perfect hyper-relational workers for online platforms, where emotional labour is ever more needed as students lack the support of peer-groups and university support staff, unlike in residential degrees. This produces a gendered new frontier of exclusion and exploitation that the academic profession needs to be aware of and resist. It presents one of the biggest challenges to feminist and progressive scholarship and activism in the next decades.

\section{Bibliography}

Advance HE. (2018). Equality in higher education: statistical report 2018. Retrieved from https://www.ecu.ac.uk/publications/equality-higher-education-statistical-report2018/.

Bennett, R. (2018, April 27). Universities sit on £44bn after tuition fee increase. The Times. Retrieved from_https://www.thetimes.co.uk/article/universities-sit-on-44bnafter-tuition-fee-increase-03ngzv8q2.

Butler, Judith (2009). Performativity, precarity, and sexual policies. Revista de Antropologia Iberoamericana, 4(1): 321-336._Retrieved from https://doi.org/10.11156/aibr.040306.

CDBU, Council of the Defence of British Universities. (2016). The Higher Education and Research Bill: What's changing? CDBU. Retrieved from http://cdbu.org.uk/thehigher-education-and-research-bill. 
Courtois, Aline \& O'Keefe, Theresa (2015). Precarity in the ivory cage:

Neoliberalism and casualisation of work in the Irish higher education sector. Journal for Critical Education Policy Studies, 13(1): 43-66.

ESF, European Science Foundation. (2009). Research careers in Europe:

Landscape and horizons. Strasbourg, France: European Science Foundation.

Retrieved from

http://www.esf.org/fileadmin/links/CEO/ResearchCareers_60p\%20A4_13Jan.pdf.

Fraser, Nancy (2016). Contradictions of capital and care. New Left Review, 100 (July/August): 99-117.

González, María José, Cortina, Clara \& Rodríguez, Jorge (2019) The Role of Gender Stereotypes in Hiring: A Field Experiment. European Sociological Review, 35(2): 187-204._Retrieved from https://doi.org/10.1093/esr/jcy055.

HolonIQ. (2019). The anatomy of an OPM and a \$7.7B market in 2025. Retrieved from https://www.holoniq.com/news/anatomy-of-an-opm/.

Ivancheva, Mariya; Lynch, Kathleen \& Keating, Kathryn (2019). Precarity, gender and care in the neoliberal academy. Gender, Work \& Organization, 26(4): 448-62. Retrieved from_ttps://doi.org/10.1111/gwao.12350.

Joseph, Ebun (2019). Precarity, gender and care in the neoliberal academy. Gender, Work \& Organization, 26(4): 448-62. Retrieved from https://doi.org/10.1111/gwao.12350.

Joseph, Ebun (2019). Discrimination against credentials in Black bodies:

Counterstories of the characteristic labour market experiences of migrants in Ireland. British Journal of Guidance \& Counselling, 24(1): 1-19. Retrieved from https://doi.org/10.1080/03069885.2019.1620916.

Hale, Thomas \& Viña, Gonzalo (2016). University challenge: the race for money, students and status. Financial Times. Retrieved from https://www.ft.com/content/c662168a-38c5-11e6-a780-b48ed7b6126f. 
Macfarlane, Bruce (2011). The morphing of academic practice: Unbundling and the rise of the para-academic. Higher Education Quarterly, 65(1): 59-73. Retrieved from_https://doi.org/10.1111/j.1468-2273.2010.00467.x.

Mansell, Robin (2017). Imaginaries of the digital: Ambiguity, power and the question of agency. Communiquer. Revue de Communication Sociale et Publique, 20(1): 40-48. Retrieved from https://doi.org/10.4000/communiquer.2261.

Marginson, Simon (2008). Global field and global imagining: Bourdieu and worldwide higher education. British Journal of Sociology of Education 29(3): 30315. Retrieved from https://doi.org/10.1080/01425690801966386.

Povey, Megan (2018). Defending pensions: a fight for all our futures. USSbriefs Nr 37. Retrieved from https://medium.com/ussbriefs/defending-pensions-a-fight-for-allour-futures-4b425cc9f360.

Rivera, Lauren, A. (2017). When two bodies are (not) a problem: Gender and relationship status discrimination in academic hiring. American Sociological Review, 82(6): 1111-38. Retrieved from_https://doi.org/10.1177/0003122417739294.

Stalford, Helen (2008). Parenting, care and mobility in the EU: Issues facing migrant scientists. Innovation: The European Journal of Social Science Research, 18(3): 361-380. Retrieved from https://doi.org/10.1080/13511610500186805.

Swinnerton, B., Ivancheva, M., Coop, T., et al. (2018). The unbundled university: Researching emerging models in an unequal landscape. In M. Bajić, N.B. Dohn, M. de Laat, P. Jandrić, \& T. Ryberg (Eds.), Proceedings of the 11th International Conference on Networked Learning 14-16 May 2018, Zagreb, Croatia (pp. 218226). Times Higher Education. (2015). Rise in teaching-only contracts. Retrieved from https://www.timeshighereducation.com/news/rise-in-teaching-onlycontracts/2019008.article.

UCU, University and College Union. (2013). Over half of universities and colleges use lecturers on zero-hour contracts. Retrieved from http://www.ucu.org.uk/6749. 
UCU, University and College Union. (2016). Precarious work in higher education. Retrieved from https://www.ucu.org.uk/media/8384/Precarious-work-in-highereducation-November-2016update/pdf/ucu_precariouscontracts_hereport_nov16_pdf.

\section{Academic praxiography}

Nanna Hlín Halldórsdóttir, University of Iceland

Thinking about academia, I often ask myself "Why am I still here?". I have endless discussions with colleagues about the wrongs of the system both on a local and a global scale. Not only about the wrongs of precarious employment and pointless hierarchies, but also the dry air during long days under fluorescent lights in standardised, impersonal class rooms. Many of us appear uncomfortable, and I experience a lot of tension in academic relations. I am not asking for a system of luxury nor perfectly comfortable space. But I need to rest, to digest and to interact with others without losing my own pace.

I used to be a fast-paced person. I grew up in and I live in Iceland. For many my country has been a sensation for the past few years, the newest "it" for the tourists, combined with what appears to be a vibrant cultural-scene and a paradise of equality. Of course, Iceland is none of those and simultaneously all of those. If I did not acknowledge the level of equality that we do have, I would be dishonoring the struggles of women and working-class people for the last decades and centuries, for example, early 20th century labor movements and the feminist Red-socks-movement in the 1970's (Porleifur, 2012; Olga, 2011).2 But for me, Iceland is just home with the goods and bads a home can have. It is the place I know best. I have lived in other

2 According to the Icelandic naming tradition, one should refer to one's given names, such as Porleifur, since 'Friðriksson' is strictly speaking not his name, but refers to his paternity. Although this confuses systems of reference within the English language, I do think it is more important to honor different naming traditions as English has become the language of international discourses and debates, both theoretically and more generally. 
places in Europe, and I have seen other places of the world with the privilege of my passport, white skin and blue eyes. I have come to realise that for many, having a home is a privilege.

When I grew up, Iceland was going through a rapid pace of neoliberalisation. As a micro-society without deeply rooted traditions, a change in hegemony happens fast in Iceland. Before the economic crash in 2008, people were excited about the neoliberal change and sincerely believed that the handsome banksters were conquering the worlds like Vikings 1000 years earlier. In this environment, I grew up as a fast-paced individual who believed I could compete and maybe win a little in the game of equal opportunities. Fortunately, the unquestionable hegemony of neoliberalism began to dismantle although the aftermath of the economic crash has been difficult and neoliberal capitalism most certainly still relies on a passive consensus from the public in accordance with Gramsci's interregnum (Rehmann, 2013; Gramsci, 2003). Unfortunately, I soon discovered that the fast pace I had embraced had never really been mine, as I had been ignoring repeating signs of chronic symptoms. In a healthcare struck by austerity I tried to find out what was wrong with me. Now, a decade later, I know that I am living with the chronic illnesses of ME/CFS and fibromyalgia.

In the state of chronic illness, academia has been a mixed blessing. I cannot work nine-to-five but I managed to complete my PhD in 2018, and now I can work as a scholar and a university teacher if I find employment. When I have a relapse in my symptoms that seems to take no end, when I cannot leave my bed, when the physical world becomes grey and dark, the fact that I have a desire for my work is a great solace. But I belong to a group of precariously employed academics and it provides me with stress and existential insecurity. Am I betting on a hopeless future? Should I be doing more in terms of securing my own academic career? My partner and I, we need to provide a stable environment for our son, academic flexibility such as getting a post-doc in Singapore or a position in the US, is not an option.

How am I to listen to my own rhythm, my own pace in this enormously competitive system of work? I came to philosophy because of a sense of wonder, frustration and 
a longing for transformation through critique, how do I stick to that path? Academia is supposed to be a system of knowledge, exploration and critique. But I have seen time and again how it punishes the people that execute a fair critique within it and out of it. How can I stick to this longing and still provide a livelihood? It has greatly empowered me to come across a critical literature on academia and how it is making us sick, such as Ann Cvetkovich's Depression: A public feeling (2012) and the collaborative article "For slow scholarship" (Mountz et al., 2015) as well as meeting colleagues internationally concerned about the very same system we find ourselves in. One of my solutions has been to go into activism concerning precarious employment in academia. As a doctoral student at the University of Iceland I started to be vocal about our situation: The lack of $\mathrm{PhD}$ and post-doctoral funding in Iceland, the lack of hiring tenured academic staff, the heavy burden and low salaries of sessional lecturers. I started opening up about the difficulties I had been experiencing as a doctoral student only to find out that this was not an individual story but a structural problem. Through FEDON (The University of Iceland's Association of Doctoral Students and Post-docs) we have managed to get the funding increased and to provide a voice for precariously employed early-career researchers in Iceland.

I am thankful for all the time I have had for reading, contemplating in solitude and conversing with other people, who have also been a great support through my own difficulties. But often I am surprised by all the time I have needed to unlearn having been moulded as a neoliberal subject, and all the books I have needed, to get to the point where I am at right now. I keep being surprised by the ever-new dimensions of my mind that yearn for recognition and desire to win the competition. These senses dispossess me and I enter a new learning curve. I am still here in academia because I want hierarchies to be smashed and learning environments to be changed but I have also come to realise that I cannot change the world by myself. Thus, I try to focus on the local spot where I am, with people sharing the same spot, and do what I can. Changes take a great amount of energy, I am tired, I need to rest but I will enter a new cycle. 


\section{Bibliography}

Árnadóttir, Olga Guðrún (Ed.). (2011). Á rauðum sokkum: Baráttukonur segja frá. Reykjavík: Háskólaútgáfan.

Cvetkovich, Ann (2012). Depression: A public feeling. Durham: Duke University Press.

Frioriksson, Porleifur. (2012). Dagar vinnu og Vona: Saga Verkamannafélagsins Dagsbrúnar í Kreppu og Köldu Stríði. Reykjavík: Sagnfræðistofnun.

Gramsci, Antonio (2003). Selections from the Prison Notebooks (Translated by Quintin Hoare and Geoffrey Nowell Smith). London: Lawrence and Wishart.

Mountz, Alison; Bonds, Anne; Mansfield, Becky; Loyd, Jenna; Hyndman, Jennifer; Walton-Roberts, Margaret; Basu, Ranu; Whitson, Risa; Hawkings, Roberta; Hamilton, Trina \& Curran, Winifred (2015). For a slow scholarship: A feminist politics of resistance through collective action in the neoliberal university. ACME: An International E-journal for Critical Geographies, 14(4): 1235-1259.

Rehmann, Jan (2013). Theories of ideology: The powers of alienation and subjection. Chicago: Haymarket Books. 